\title{
A canonical correlation analysis of savings and loan association performance
}

\author{
MICHAEL L. MARLOW \\ Department of Economics, George Washington University, USA
}

\section{INTRODUCTION}

The banking structure-performance relationship has been the subject of many studies (Heggestad, 1979). This paper addresses two problems associated with previous research through analysis of the structure-performance relationship in the savings and loan association industry. One problem is that most studies estimate the structure-performance relationship with multiple regression analysis. The problem with using this technique is that only a single measure of performance may be studied at one time, rather than a set of measures. Such a set might include hours of operation, loan rates, deposit rates, service charges and profitability. A more general study of performance should include more than one measure. A second problem is that it is difficult to determine the relative contributions of all factors which affect performance, such as demand, product market, costs and market structure factors. It would prove useful to determine the relative importance of factors which affect performance when considering changes in regulatory policy.

This paper avoids these problems through the use of canonical correlation analysis. This technique allows one to test for the effects of explanatory factors upon multidimensional measures of performance. While this technique is not widely used in the structure-performance literature, it has been used by Fraser et al. (1974) in their study of commercial banks in Texas for the years 1969 and 1970 . Fraser $e t$ al. (1974) find that market structure variables are of the second order of importance in explaining measures of performance, with cost, deposit and loan composition, and demographic factors being relatively more important. ${ }^{1}$ The tests presented here are on savings and loan associations operating within 153 Standard Metropolitan Statistical Areas (SMSAs) in 1979. The conclusion that is reached in this paper is that market structure is very important in determining performance. Reasons to explain the difference between the two studies are presented as well as implications for regulatory policy.

\footnotetext{
'Their measures of performance were three measures of the price of bank services, one measure of profit, and one measure of bank output.
} 


\section{BRIEF DISCUSSION OF THE PROCEDURE ${ }^{2}$}

Canonical correlation is a multivariate technique that is used to study the relationship between two groups of variables. One group consists of dependent variables and the other consists of explanatory or independent variables. For example, the relationship may be shown as

$$
g\left(P_{\imath}\right)=f\left(E_{1}, \mathrm{E}_{2}, \ldots, E_{n}\right)
$$

where $P_{i}(i=1, \ldots, m)$ are individual measures of performance and $E_{j}(j=1,2, \ldots, n)$ are sets of explanatory measures of performance. Two steps for each of the two groups of variables are performed. First, canonical analysis determines linear combinations of the explanatory variables that are most highly correlated with linear combinations of the measures of performance. That is, a linear combination of variables, called a canonical variable, is found such that the correlation between the two canonical variables is maximized. Canonical correlation is then this relation between the two canonical variables. The second step consists of determining a second set of canonical variables, which produces the second highest correlation coefficient. This process of determining canonical variables is continued until the number of variables in the second group is equal to the number of pairs of canonical variables.

The following statistics are of interest to us. The canonical correlation index is the overall correiation between the set of dependent variables. The F-statistic on the estimated value of Wilks' Lamda allows us to test the significance of the canonical correlation index. The canonical $R^{2}$ estimates the degree of variability in the dependent variables that is explained by the explanatory variables.

\section{AN EMPIRICAL MODEL}

The following relationship is used since it is the one that is usually chosen by researchers of the structure-performance relationship (Heggestad, 1979)

$$
g\left(P_{1}, P_{2}, P_{3}\right)=f\left(D_{1}, D_{2}, C_{1}, C_{2}, M S_{1}, M S_{2}, M S_{3}, M S_{4}, X_{1}, X_{2}, X_{3}\right)
$$

where the variables chosen to represent these factors are: ${ }^{3}$

\section{Performance measures}

$P_{1}=$ average loan rate (interest plus fees on mortgages/volume of mortgages)

$P_{2}=$ average profitability (net income/total assets)

$P_{3}=$ average deposit rate (interest and dividends on savings accounts $/$ savings accounts).

\footnotetext{
-See Kendall (1961) for a description of this procedure.

${ }^{3}$ All data are calculated on an annual basis. The data on the savngs and loan industry is obtaned from the Federal Home Loan Bank Board's Combined Finuncial Statements. 1979, and unpublished files. The data on commercial banks and mutual savings banks is from the Federal Deposit Insurance Corporation's Summary of Deposits.
} 


\section{Market demand conditions}

$D_{1}=$ percentage change in population between 1970 and 1978

$D_{2}=$ percentage change in deposits between 1970 and 1979.

Cost differences

$C_{1}=$ labour costs (compensation and other benefits/total assets)

$C_{2}=$ office costs (office occupancy costs/total assets).

\section{Market structure characteristics}

$M S_{1}=$ five-firm deposit concentration ratio for savings and loan associations

$M S_{2}=$ number of firms (number of savings and loan associations/population in 1978)

$M S_{3}=$ number of competing firms (number of commercial banks and mutual savings banks/population in 1978)

$M S_{4}=$ presence or absence of mutual savings banks.

\section{Loan market characteristics}

$X_{1}=$ proportion of mortgage loans to total assets

$X_{2}=$ proportion of unsecured property improvement loans to total assets

$X_{3}=$ proportion of cash and investment securities to total assets.

The sample consists of 153 SMSAs and includes data on 2143 savings and loan associations in 1979. The measures of performance are those that have been used before in univariate tests (Heggestad, 1979). The market demand variables are included to control for differences in demand conditions that may affect performance across SMSAs (Davis and Verbrugge, 1980; Aspinwall, 1970; and Kaufman, 1966). The year 1978 was chosen for the construction of $D_{1}$ due to the lack of data for 1979. Variables used to measure cost differences are used to hold constant the effects of differences in the costs of operation on measures of performance (Verbrugge and Schick, 1976 and Fraser and Rose, 1971). Market structure variables are used to allow performance to be affected by differences in the level of competition. Both $M S_{1}$ and $M S_{2}$ are standard measures of market structure. ${ }^{4}$ The number of competing firms $\left(M S_{3}\right)$ is included since previous studies have found that there does exist some degree of competition between commercial banks, savings and loan associations, and mutual savings banks (Davis and Verbrugge, 1980; Heggestad and Mingo, 1976; White, 1976). A dummy variable $\left(M S_{4}\right)$ for the presence or absence of mutual savings banks is included since not all states allow mutual savings banks. Since mutual savings banks, like savings and loan associations, invest a large proportion of their assets in mortgages, their presence may exert a significant impact on savings and loan association performance. For this sample, 119 of the SMSAs do not allow mutual savings banks. Loan market variables control for the fact that interest rates and profitability

${ }^{4}$ Longbrake and Peterson (1979), Fraser and Rose (1971) and Aspinwall (1970) find both the numbers of firms and concentration ratios to be significant factors in explaining differentials in the interest rates on loans. 
should vary with the type and risk characteristics of loans. ${ }^{5}$ Therefore, differences in the loan markets of savings and loan associations explain that part of the variation in performance measures across SMSAs that is associated with differences in the economic characteristics of loans.

\section{THE RESULTS}

Two steps are taken to determine the overall relationship between the set of performance variables and the sets of explanatory variables. The first step is to determine the canonical correlation index between these two sets of dependent and explanatory variables. Table 1 shows this index for the model with 11 independent variables. The first and second canonical correlation indices are 0.7096 and 0.4300 , respectively. The F-test allows us not to reject the hypothesis, at the 0.01 level, that there exists a significant relationship between the 11 independent variables and the three measures of performance. The canonical correlation $R^{2} \mathrm{~s}$ are 0.50 and 0.19 , respectively, for the first and second indices.

The second step is to determine the canonical correlation index for each of the four sets of explanatory variables separately. This allows us to rank them in terms of relative importance. These results are also displayed in Table 1. For the first index, product market characteristics are found to rank first in importance. This indicates that performance measures vary with the type and risk characteristics of loans. Market structure and market demand sets of variables rank, respectively, second and third. The only set of variables that does not exert a significant effect on performance is cost differences. ${ }^{6}$

The second canonical correlation indices show that only market structure and market demand characteristics exert significant impacts. While this index is not as interesting as the first canonical index, it does serve to present even stronger evidence that market structure does exert a significant impact on performance and, in fact, becomes the most important determinant in terms of rank. ${ }^{7}$

\footnotetext{
${ }^{\text {s}}$ For example, Davis and Verbrugge (1980) find the proportions of installment and construction loans to mortgages affect loan rates positively.

${ }^{6}$ Cost differences are found to rank first in Fraser et al. (1971). One reason for this difference may be that this explanatory variable serves as a proxy for economes of scale. Fraser et al. (1971) only analyse banks in the unit banking state of Texas. This serves to suggest that there are significant differences from costs on performance in unit banking areas but that in a broader sample, with all types of structure included, there are no stgnificant differences.

${ }^{7}$ As suggested in Fraser et al. (1971), one is most interested in the first canonical relationship since always displays the largest index. The second canonical relationship is the linear combination determined by maximizing the correlation between the two canonical variables such that they are uncorrelated with the first linear combination.
} 
Table 1. Canonical correlation indices for various sets of independent variables

\begin{tabular}{|c|c|c|c|c|c|c|c|c|}
\hline \multirow[b]{2}{*}{ Sets of Variables } & \multicolumn{4}{|c|}{ First Canonical Correlation } & \multicolumn{4}{|c|}{ Second Canonical Correlation } \\
\hline & Indices & F-Statistic & $R^{2}$ & Rank & Indices & F-Statistic & $R^{2}$ & Rank \\
\hline All 11 variables & $0.7096^{*}$ & 5.40 & 0.50 & & $0.4300^{*}$ & 2.78 & 0.19 & \\
\hline Market demand & $0.3249^{*}$ & 4.18 & 0.11 & 3 & $0.2231 * *$ & 3.90 & 0.05 & 2 \\
\hline Cost differences & 0.2341 & 1.74 & 0.05 & 4 & 0.1140 & 0.98 & 0.05 & 4 \\
\hline Market structure & $0.3396^{*}$ & 2.58 & 0.11 & 2 & $0.2760^{* * *}$ & 2.04 & 0.08 & 1 \\
\hline Product market & $0.6279^{*}$ & 9.89 & 0.39 & 1 & 0.1964 & 1.47 & 0.39 & 3 \\
\hline
\end{tabular}

* Significant at the 0.01 level

* Significant at the 0.05 level

** Significant at the 0.10 level

\section{CONCLUSION}

These results indicate that, ceteris paribus, sets of loan market, market structure, and market demand variables are important in the determination of performance.

It is not surprising that loan market variables are found to be the most important determinant of performance. This result probably has much to do with the way in which performance is measured. For example, high levels of borrower risk, ceteris paribus, have been found to be associated with high levels of interest rates (Davis and Verbrugge, 1980; Longbrake and Peterson, 1979; and Aspinwall, 1970). Therefore, part of the variation in measures of performance may result from differences in the economic characteristics of loans, rather than from differences in noneconomic factors. Since the relationship between levels of risk and interest rates may not generate implications for regulatory reform, other measures of performance should be included in future studies. At the very least, regulators should recognize that the characteristics of loan markets affect the above measures of performance and that such measures of loan characteristics may be unrelated to market structure. Other measures of performance which might be studied include the interest rate for a well defined and homogeneous product such as a 30-year conventional mortgage with $90 \%$ loan-to-value ratios.

Unlike the results found by Fraser et al. (1974), market structure appears to be very important. Two possible reasons could account for this difference. One is that Fraser et al. (1974) study the commercial banking industry while the present study has analysed savings and loan associations. The other is that Fraser et al. (1974) consider only one state, Texas, which is subject to unit banking laws. The present study analyses data on SMSAs subject to all forms of regulation. One would expect there to exist wider variations in market structure (and thus stronger significance in measuring variations in performance) when sample observations are taken across many more diverse markets. Further research is therefore necessary before one may suggest that these differences in the structure-performance relationship of commercial banking and savings and loan markets actually exist. The policy implication is that changes in the regulation of market structure will affect performance in the savings and loan association 
industry. Future research in this area should be directed toward suggesting ways in which structure may be changed through regulatory reform so as to improve performance.

\section{REFERENCES}

Aspinwall, R. C. (1970) Market structure and commercial bank interest rates, Southern Economic Journal, 36, 376-84.

Davis, H. M. and Verbrugge, A. (1980) Structure and performance in the savings and loan industry, Journal of Economics and Business, 31, 40-51.

Fraser, D. R., Phillips, W. and Rose, P. S. (1974) A canonical analysis of bank performance, Journal of Financial and Quantitative Analysis, 9, 287-95.

Fraser, D. R. and Rose, S. (1971) More on banking structure and performance: the evidence from Texas, Journal of Financial and Quantitative Analysis, 6, 601-11.

Federal Deposit Insurance Corporation, (1970, 1978 and 1979) Summary of Deposits, Washington, DC. Federal Home Loan Bank Board, (1970, 1978 and 1979) Combined Financial Statements, Washington, DC.

Heggestad, A. A. and Mingo, J. (1976) Prices, nonprices and concentration in commercial banking, Journal of Money, Credit, and Banking, 8, 107-17.

Heggestad, A. A. (1979) A survey of studies on banking competition and performance, in Issues in Financial Regulation (Ed.) F. R. Edwards, McGraw-Hill, New York.

Kaufman, G. C. (1966) Bank market structure and performance: the evidence from Iowa, Southern Economic Journal, 32, 429-39.

Kendall, M. G. (1961) A Course in Multivariate Analysis. Charles Griffin and Co. Ltd, London.

Longbrake, W. A. and Peterson, M. O. (1979) Regional and intraregional variations in mortgage loan rates, Journal of Economics and Business, 31, 75-83.

Verbrugge, J. A. and Shick, R. A. (1976) Market structure and savings and loan profitability, Quarterly Review of Economics and Business, 16, 79-90.

White, L. S. (1976) Price regulation and quality rivalry in a profit-maximizing model: the case of branch banking, Journal of Money, Credit, and Banking, 8, 97-106. 